\section{Growing up in the permafrost}

\section{Robert Foley}

Reindeer Moon. By Elizabeth Marshall Thomas. Houghton Mifflin:1987. Pp.338. $\$ 17.95$

Whatever you do, don't let your daughter marry a mammoth hunter. They beat their wives, they think about nothing but their work (hunting) and they tell boring stories about their relatives. Worse, they make their wives wear baggy trousers, not only a travesty of fashion for a self-respecting woman of the Fire River, but also impractical if you have to climb a tree to escape a lion.

Of course, the opportunities for marrying mammoth hunters are limited, for they lived 20,000 years ago and in all probability exist only in the imagination of Ms Thomas, the author of Reindeer Moon. In the usual sort of Nature review this last comment would be damning criticism, but in this case it is not.

Reindeer Moon is a novel. It tells the story of Yannan, a young girl growing up in the permafrost. Orphaned, starved and married, she survives all these hazards of the Eurasian steppes during the last ice age; survives until page 27 , that is. From then on there are really two tales running in parallel - one, the story of Yannan as a young woman facing the tribulations of a harsh natural and social environment; the other, Yannan transformed into a spirit after death, looking down on the incessant struggle for food continued by the survivors.

Her life was certainly hard as well as short, and this book is by no means a representation of prehistoric man as the noble savage that one might have expected from the author of The Harmless People. Any harmony that human beings had with nature derived solely from the fragile hold on life that they must have had in the bleak and endless steppes of the last glaciation. The story of Yannan's life is exhausting - ever-present hunger, satisfied only momentarily by hunting, a relentless need for firewood to ward off the biting cold, with predators, septicaemia and death in childbirth as more intermittent risks in case these others relent. The price of survival is constant social interaction - communal living to maintain warmth, economic interdependence, and marriages and alliances forced by the need for access to resources. The association between the people of the Fire River and the boorish mammoth hunters of the adjacent valley is one such alliance, bringing with it security of food at the cost of social and emotional conflict. Biting arctic winds and oppressive social claus- trophobia alternate as the pervasive themes of the book.

To some extent Ms Thomas has written a Pleistocene soap opera, an up-market Clan of the Cave Bear. But her book is more than that. She manages to evoke the beauty of these arctic environments without losing sight (or, more particularly, the smell) of their hostility. Her research has been painstaking, incorporating a detailed knowledge of the habits and habitats of the plants and animals of Eurasian steppe with some imaginative anthropological reconstruction. The force of accuracy is weakened by the fact that the spirit world after death is presented with the same degree of realism as the lost prehistoric world, but the book imparts vividly the atmosphere of living at that time. Reindeer Moon started as a piece of scientific research into prehistoric huntergatherer ecology, and this may account for

\section{Repair in the dark}

\section{Tomas Lindahl}

Molecular Biology of DNA Repair. Edited by A. Collins, R.T. Johnson and J.M. Boyle. The Company of Biologists, Department of Zoology, University of Cambridge, Downing Street, Cambridge CB2 3EJ, UK: 1987. Pp.353. £35, \$70.

IN THE celebrated concluding statement to their first 1953 paper on DNA, Watson and Crick commented that "It has not escaped our notice that the specific pairing we have postulated immediately suggests a possible copying mechanism for the genetic material". This remark and the subsequent discussions of DNA replication may be contrasted with an afterthought by Crick in a review 21 years later: "We totally missed the possible roles of enzymes in repair".

DNA repair has continued to escape the attention of most molecular biologists, as witnessed by the cursory and erroneous coverage of the subject in the textbook Molecular Cell Biology by Darnell, Lodish, and Baltimore, published last year by W.H. Freeman. This state of affairs is unfortunate and surprising. Cells suffer so many forms of spontaneous and induced damage to their genomes that a multitude of different pathways and mechanisms of repair have evolved, and these processes are instrumental in preventing unacceptable levels of mutagenesis and carcinogenesis. Indeed, a larger part of the cellular enzymatic machinery for nucleic acid metabolism seems to have been devoted to working out the many small problems of DNA repair than to solving the single towering question of DNA replication.

Although occasional highlights of re- its seamless continuity between fact and fiction.

The Reindeer Moon of the title refers to the name of one of the months, and the story passes through many moons, each reflecting an annual event - the icebreaking moon, the yellowleaf moon, the hunger moon and so on. At first this is confusing, but it is soon infectious and one realizes how remote the names of our months are from the realities of everyday life. It is time, perhaps, to revitalize the academic calendar to reflect the trials of contemporary life. So how about the Month of Grant Proposals Due, the Month of Disappointment, and that hardy British perennial, the Month of UGC Cuts?

Robert Foley is a Lecturer in the Department of Physical Anthropology, University of Cambridge, Downing Street, Cambridge CB2 3DZ, UK.

pair studies may appear in the betterknown publications, much of the solid groundwork in this field is to be found in cancer journals or those specializing in mutation and radiation research or genetic toxicology. An authoritative overview of the molecular biology of DNA repair was long needed, and arrived in the form of Errol Friedberg's excellent $D N A$ Repair (published by W.H. Freeman in 1985). This is the book against which all others on the subject have to be measured.

The volume under review consists of a series of articles and reviews representing contributions to a conference held in Manchester in 1986. Compared with Friedberg, the coverage is patchy - some aspects of the field are usefully brought up to date, but on others, such as photoreactivation where the previous book is already out of date, there is no information at all. Most of the contributions come from European laboratories and many are of uneven quality.

There are, however, a thoughtful concluding review on mutagenesis and cell killing in mammalian cells by methylating agents, and informative articles on inducible DNA repair systems and excision repair in Drosophila and human cells. Also, the editors (who somewhat pretentiously refer to themselves as the DNA Repair Information Network) have compiled a useful and extensively referenced catalogue of the many different DNA repair mutants that have been described in higher eukaryotes.

The book is elegantly produced. Taken as a symposium volume it is somewhat fragmentary in content, but above average in quality.

Tomas Lindahl is Head of the Clare Hall Laboratories, Imperial Cancer Research Fund, South Mimms, Hertfordshire EN6 $3 L D, U K$. 